Murtiningsih : The Effect of Abdominal Stretching Exercise on Dysmenorrhea in Adolescent Girls

\title{
THE EFFECT OF ABDOMINAL STRETCHING EXERCISE ON DYSMENORRHEA IN ADOLESCENT GIRLS
}

\author{
Murtiningsih $^{1}$, Lilis Solihah ${ }^{1}$, Sri Yuniarti ${ }^{1}$ \\ ${ }^{1}$ Institute of Health Science Jend A Yani, Cimahi, Jawa Barat, Indonesia \\ Corresponding email: murty_68@yahoo.com
}

\begin{abstract}
Based on my survey in February 2018 at the three SMA Negeri Cimahi, 956 adolescent girls (67.2\%) from 1.422 of female students had experienced dysmenorrhea. Dysmenorrhea is disturbed young women's study activities at school. The preliminary study found that 10 teenagers had dysmenorrhea, 4 of them said they could not follow the sporting activities. This research aimed to determine the effect of abdominal stretching exercise in reducing the pain due to dysmenorrhea in the adolescent girls. The method used a quasi-experiment design with one group pretestposttest. The population in this study was 174 peoples and obtained 19 samples with random sampling technique. Pain score measured by the Verbal Descriptor Scale before and after given the abdominal stretching exercises for 15 minutes, 3 times during 7 days with an interval of one day. Data analysis used univariate test and t-dependent test. The results of the study obtained the pain score before the abdominal stretching exercises were 6.16 scale (moderate pain) and after abdominal stretching exercises was 2.37 scale (mild pain) with pain scale difference 3.79 . Tdependent statistical test obtained that p-value $<0,001$, it refers to abdominal stretching exercises affects in decreasing pain scale of dysmenorrhea. Abdominal stretching exercises are recommended as an influential intervention of dysmenorrhea for adolescent girls. This exercises can be a new routine activity for adolescent girls since it is very beneficial for them.
\end{abstract}

Keywords: Abdominal stretching, adolescent girls, dysmenorrhea, exercises.

\section{INTRODUCTION}

The prevalence of dysmenorrhea was $77.6 \%$ and only $8 \%$ of them performed physical exercises (Gabeyehu, MB et al, 2017). The results of the research Center of Information and Counseling for Adolescent Reproductive Health (PIK-KRR) indicate that the number of dysmenorrhea incidence ranges from $45-95 \%$ in productive women, consisting of $72.89 \%$ primary dysmenorrhea and $27.11 \%$ secondary dysmenorrhea (Proverawati \& Misaroh, 2009). Primary dysmenorrhea mainly affects adolescent girls in the age of 12-20 years old (Sultan C, Gaspari L, Paris F, 2012). Nowadays, the number of incidents of dysmenorrhea in West Java is not known. Based on a research survey in February 2018 at the three SMA Negeri Cimahi, from 1,422 of adolescent girls, 956 adolescent girls (67.2\%) have undergone dysmenorrhea.

Dysmenorrhea significantly had negative effects on adolescent girls because it disrupts daily activities. If students experience dysmenorrhea, their learning activities will be interrupted and sometimes they do not go to school. Those who experience dysmenorrhea had reduced their study focus in class, and dysmenorrhea makes them uncomfortable to lower motivation during the learning process (Ningsih, 2011). 
Murtiningsih : The Effect of Abdominal Stretching Exercise on Dysmenorrhea in Adolescent Girls

More than two thirds $(63.8 \%)$ of the adolescent girls use home remedies as a primary management option (Gabeyehu, MB et al, 2017). One of the appropriate treatment of dysmenorrhea for adolescent age is physical exercise. In conducting exercise the body will produce endorphins that are produced by the brain and spinal nerves. Endorphin hormone serves as a natural sedative, thus giving rise to a sense of relaxing and comfort (Arifin, S, 2008). According to Harry (2007) exercise proved to increase the levels of $\beta$-endorphin four to five times in the blood. So the more exercise, the higher the level of ${ }^{\beta}$-endorphin. When a person is doing exercise, then ${ }^{\beta}$-endorphins will come out and be caught by receptors within the hypothalamus and limbic system that serve to regulate emotions. Increasing $\beta_{-}$ endorphins proved to be closely related to the decline in pain, increase of memory, improve the appetite, sexual ability, blood pressure, and breathing. Physical exercise that can be used to reduce dysmenorrhea during menstruation is by doing abdominal stretching exercise (Thermacare, 2010).

The abdominal stretching exercise is a physical exercise by stretching the muscles especially stomach for 10-15 minutes. This exercise is specifically designed to improve muscle strength, endurance, and flexibility of muscles, to reduce muscle tension, improve blood circulation, reduce anxiety, reduce the risk of injury (Anderson, 2010). It is expected that it would be lowering pain in the dysmenorrhea period. This exercise is a combination of six motion paint stretch, lower trunk rotation, buttock/hip stretch, abdominal strengthening (curl up), lower abdominal strengthening and the bridge position (Thermacare, 2010). Daley (2009) believed that contracted ligamentous bands in the abdominal region were the causative factor physical compression of nerve pathways and their irritation, so the proposed series of stretching abdominal exercises was considered very effective.

Salbiah has done research (2012) and showed that there was an influence before and after abdominal exercises stretching. She gave intervention an abdominal stretching exercise before menstruation and the respondents were given drinking water. Based on preliminary studies on the 10 dysmenorrhea students, 6 of them said they could follow the sport when learning sports and 4 people do not follow the sport. They have not known physical exercise with abdominal stretching to reduce dysmenorrhea. This research aimed to determine the effect of abdominal stretching exercise in reducing the pain due to dysmenorrhea in the adolescent girls at SMA Negeri 5 Cimahi.

\section{METHODS}

This research has used the pre-experiment design method with one group pre-test post-test. Population in this research was all adolescent girls who had dysmenorrhea with a total of 174 peoples. The sampling technique in this study was probability sampling with a stratified random sampling approach. The sample in this study was 19 adolescent girls. Respondents must have the following inclusion criteria: the 
Murtiningsih : The Effect of Abdominal Stretching Exercise on Dysmenorrhea in Adolescent Girls

respondent with regular menstruation every month for 1 year or more, the dysmenorrhea at $1-24$ hours and they always experiencing dysmenorrhea each month. ,

The inclusion criteria of the sample were a student with menstrual pain in the first 24 hours. They have dysmenorrhea every month, no diagnosis of pelvic inflammatory diseases, uterine abnormalities, endometriosis, no fractures, and bone injuries, not in medication or traditional treatment, and not following a specific method to reduce pain. The researcher measured the pain scale of dysmenorrhea before the intervention. The intervention of abdominal stretching exercise for 15 minutes, 3 times during 7 days with an interval of one day, carried out before menstruation next month. After the intervention, the measurement of the pain scale of dysmenorrhea in the first 24 hours of menstruation. Before data collection, the researcher explained the research procedure to respondents.

Respondents who voluntarily agreed to participate in the study were asked to sign an informed consent sheet. There is no compulsion to be a respondent, they are allowed to resign during the research procedure. Data collection starts at the time of the first day's menstrual respondent. The first measurement (pre-test) is done using respondents filling in the pain scale questionnaire (Numeric Rating Scale). Intervention is performed three weeks after menstruation with abdominal exercises stretching for 15 minutes, 3 times during 7 days with 1-day interval. The second measurement (post-test) was done after abdominal stretching exercises 3 times, respondents filled in the pain scale questionnaire. Data analysis used univariate test and t-dependent test. This study was approved by the research ethics committee of Institute of Health Science Jend A Yani, Cimahi, Jawa Barat, Indonesia

\section{RESULTS}

Tabel 1 The average the pain scale of dysmenorrhea in adolescent girls before abdominal stretching exercises

\begin{tabular}{clcccc}
\hline Variable & Measurement & Mean & SD & $\begin{array}{c}\text { Minimum- } \\
\text { Maximum }\end{array}$ & $95 \%$ \\
& & & & \\
\hline Pain Scale & Pre-test & 6.16 & 1.344 & $4-8$ & $\begin{array}{r}5.51- \\
6.81\end{array}$ \\
& & & & & \\
\hline
\end{tabular}


Murtiningsih : The Effect of Abdominal Stretching Exercise on Dysmenorrhea in Adolescent Girls

Tabel 2 The average of the pain scale of dysmenorrhea in adolescent girls after abdominal stretching exercises

\begin{tabular}{lccccc}
\hline Variable & Measurement & Mean & SD & $\begin{array}{l}\text { Minimum- } \\
\text { Maximum }\end{array}$ & 95\% CI \\
\hline $\begin{array}{l}\text { Pain } \\
\text { scale }\end{array}$ & Post-test & 2.37 & 0.895 & $1-4$ & $1.94-2.80$ \\
\hline
\end{tabular}

Tabel 1 The differences in the pain scale of dysmenorrhea in adolescent girls before and after abdominal stretching exercises.

\begin{tabular}{|c|c|c|c|c|c|c|}
\hline Variable & Measurement & $\mathrm{N}$ & Mean & $\mathrm{SD}$ & $\begin{array}{c}\text { Difference } \\
\text { Scale }\end{array}$ & P-value \\
\hline & Pre-test & & 6.16 & 1.344 & & \\
\hline $\begin{array}{l}\text { Pain } \\
\text { scale }\end{array}$ & Post-test & 19 & 2.37 & 0.895 & 3.79 & 0.001 \\
\hline
\end{tabular}

Table 3 shows that the differences of the pain scale of dysmenorrhea before abdominal stretching exercises was 6.16 scale (moderate pain) with deviation standard 1.344 and after abdominal stretching exercises was 2.37 scale (mild pain) with deviation standard 0.895, with pain scale difference 3.79. Statistical test obtained that $\mathrm{p}$-value $<0,001$, it refers to abdominal stretching exercises affects to decrease pain scale of dysmenorrhea in adolescent girls.

\section{DISCUSSION}

The average pain scale of dysmenorrhea in adolescent girls before abdominal stretching exercises.

The finding shows that average the pain scale of dysmenorrhea in adolescent girls before abdominal stretching exercises was 6.16. That means moderate pain scale of dysmenorrhea. The lowest pain was 4.0 (moderate pain) and the highest pain was 8 (severe pain) with a range of 1 to 10. Another research by Hidayah (2015) prove this finding which stated that 6 adolescent girls experienced mild pain, 8 adolescent girls experienced moderate pain and 1 adolescent girl experienced severe pain before abdominal stretching exercises. The average pain scale of dysmenorrhea was 4.6 with moderate pain. Another research by Salbiah (2012) was obtained average pain scale of dysmenorrhea in adolescent girls before abdominal stretching exercises was 4.18. It means moderate pain scale of dysmenorrhea. 
Murtiningsih : The Effect of Abdominal Stretching Exercise on Dysmenorrhea in Adolescent Girls

The level of respondent pain was different, they felt uncomfortable, tired, sick, and interfere with daily activities. Each menstrual period causes pain, especially at the beginning of menstruation flow, but with varying levels of the pain, such as mild pain, moderate pain, and severity pain. The dysmenorrhea was strongly influenced by several factors such as fatigue, psychic, and endocrine factors. So that the pain intensity that an individual feels varies (Proverawati \& Misaroh, 2009).

The level of dysmenorrhea often causes negative effects on young women. Pain experienced by young women will bring young women to unpleasant conditions that can interfere with daily activities and lower concentration while studying in school. Seeing from these impacts, it can be said that dysmenorrhea is one of the problems of young women (Proverawati \& Misaroh, 2009). The results of research obtained that the average pain levels of dysmenorrhea experienced by adolescent girls was a moderate pain. The numerical rating scale (NRS) is designed to be used by those over age 9 . The scale from 0 to 10 or to place a mark on a line indicating the level of pain. Zero indicates the absence of pain, while 10 represents the worst possible pain. Pain is classified into mild pain with a scale of 1 to 3 , moderate pain with a scale 4 to 6 , and severe pain with a scale 7 to 10 (Pasero \& Chris, 2011).

During menstruation, the uterus had spasm more powerful (Potter \& Perry, 2010). This pain is because of overproduction of uterine prostaglandin F-2 $\alpha$ which induces myometrium hypercontractility and arthroscope vasoconstriction, both involved in painful menstrual cramps (S Saleh H, E Mowafy H, Hamied AA and El, 2016). Primary dysmenorrhea is caused by excess prostaglandin $F_{2 \alpha}$ in the endometrium. The prostaglandin production in the uterus normally increases under the influence of progesterone, reaching a peak at, or soon after, the start of menstruation. With the onset of menstruation, formed prostaglandins are released from the shedding endometrium. Prostaglandins are potent smoothmuscle stimulants that cause intense uterine contractions, resulting in intrauterine pressure that can exceed $400 \mathrm{~mm} \mathrm{Hg}$ and baseline intrauterine pressures over $80 \mathrm{~mm} \mathrm{Hg}$. Prostaglandin $\mathrm{F}_{2 \alpha}$ also causes a contraction in smooth muscle elsewhere in the body, resulting in nausea, vomiting, and diarrhea. In addition to the increases in prostaglandins from endometrial shedding, necrosis of endometrial cells provides increased substrate arachidonic acid from cell walls for prostaglandin synthesis (Dauglas W.Laube et al, 2010).

The characteristic of the respondent on this study that the average age of the menarche was 12 years old. The average has been dysmenorrhea at the age of 14 years old. Ningsih's research (2011) found that dysmenorrhea generally occurs after 1 to 3 years experienced the menarche. The results of Yanti's research (2012) found that the average teenager who often experienced dysmenorrhea at the age before 16 
Murtiningsih : The Effect of Abdominal Stretching Exercise on Dysmenorrhea in Adolescent Girls

years old. The incidence of primary dysmenorrhea is greatest in women in their late teens the to early $20 \mathrm{~s}$ and declines with age (Dauglas W.Laube et al, 2010). This occurs due to the hypothalamus-pituitary ovarian endocrine axis response, the follicle ovarium response, and uterus function has begun to normal.

\section{The average pain scale of dysmenorrhea after the intervention of abdominal stretching exercises.}

The results of the analysis of the research data obtained that the average of the pain scale of dysmenorrhea in the adolescent girls after an abdominal stretching exercise intervention was 2.37 with a standard deviation of 0.895 which means the average of pain scale felt at the level of mild pain of dysmenorrhea. The results showed that the lowest pain scale before given abdominal stretching exercise intervention was 1 and the highest pain scale was 4 from the range of 1-10.

The results of this research were similar to the research results of Hidayah (2015) that from 15 respondents after being given abdominal stretching exercises there were 14 adolescent girls experiencing mild pain with a percentage of $93.3 \%$, one adolescent girl experiencing moderate pain with a percentage of $6.7 \%$ and no one was experiencing severe pain. The data showed that the average dysmenorrhea that is felt by the respondents after the abdominal stretching exercises were 2.13 with a standard deviation of 1.356, that means that the average of pain scale that is given after intervention abdominal stretching exercises was at the level of mild pain of dysmenorrhea. The results of the research of Salbiah (2012) were obtained on average the painful scale that was given by the abdominal stretching exercise was 1.96 which means the average pain scale of dysmenorrhea at the rate of mild pain of dysmenorrhea.

The occurrence of average decrease in the pain of the dysmenorrhea is caused by the occurrence of vasopressin decreases in the decrease of uterine contractions so that hypoxia and ischemia in the uterine tissues do not occur due to training movements abdominal stretching exercise that is done naturally will stimulate the production of endorphin hormones in the body (Rosemary, 2007). Endorphin hormones are chemical compounds produced by the pituitary gland located at the bottom of the brain. The endorphin hormone serves as a natural sedative, giving rise to a relaxed and comfortable feeling. Endorphin hormones also function to block the opioid receptors found in nerve cells and cause the disruption of the transmission of pain signals to stop the pain sensation and the response to pain naturally produced by the body. Increasing levels of endorphins in the body can reduce pain during contraction. Physical exercise is one of relaxation techniques to reduce the pain felt by stimulating an increase of four to five times the levels of endorphins that serve as natural analgesics produced by the body, causing pain is perceived to be diminished and lost, thus endorphins are considered to be a pain relief substance (Harry, 2007). 
Murtiningsih : The Effect of Abdominal Stretching Exercise on Dysmenorrhea in Adolescent Girls

\section{The effect of abdominal stretching exercises to dysmenorrhea in adolescent girls.}

The statistical test result founded that $\mathrm{p}$-value $<0.001$. It is showed that abdominal stretching exercises significantly affects to reduce dysmenorrhea in adolescent girls. The results of this study were supported by the previous research conducted by Hidayah (2015) which proved that abdominal stretching exercises affect to pain scale of dysmenorrhea. The research by Salbiah (2012) that the average scale of the pain of dysmenorrhea was decline after given abdominal stretching exercise intervention with p-value $=0.0001<$ $\alpha 0.05$, which means there is a significant influence abdominal exercises stretching to lower the scale of dysmenorrhea perceived by respondents.

In this research, these pain scale before abdominal stretching exercises reach to 6.16 (moderate pain) scale and after abdominal stretching exercises they reduce into 2.37 (mild pain) scale, the results decreased 3.79 points. The positive effect of abdominal stretching exercises derived by the successful research. The abdominal stretching exercises are conducted in a clean, neat and clear in respondent's room. This comfortable room makes all of the respondents can concentrate and be comfortable. The abdominal stretching exercises suggested for young women to deal with primary dysmenorrhea in a nondrug manner (Bustan, M Najib, 2018).

Abdominal stretching exercises are one of the non-pharmacological interventions that can be performed to prevent and reduce the dysmenorrhea pain experienced by adolescent girls. Abdominal stretching exercise interventions provided consist of regular and structured movements that can naturally stimulate the mechanoreceptor and neuron beta $\mathrm{A}$ to faster release of the inhibitory neurotransmitter. The mechanism of defense or the pain gate called a Subtansia Gelatunisa is closed and causes stimulation in weak $\mathrm{T}$ cells. Cortex cerebrum is unable to receive pain messages from the spinal cord so that the pain response is reduced (Danuatmaja, 2008).

The physical exercises are beneficial to improve and maintain the health and endurance of the heart, lungs, circulatory, muscles, and joints. Physical exercise has 4 basic components of muscle strength, the flexibility of muscular endurance and cardiorespiratory endurance. The effect of physical exercise will provide a physiological change that almost occurs in every system of the body. Physical exercise will have a good influence on the various systems that work in the body. One of which is a cardiovascular system, with proper and regular physical exercise will occur the efficiency of cardiac work. The efficiency of heart work or heart ability will increase according to the changes that occur. By doing physical exercise the veins are experiencing widening and relaxation. One of the factors of dysmenorrhea 
Murtiningsih : The Effect of Abdominal Stretching Exercise on Dysmenorrhea in Adolescent Girls

is the contraction of the uterine wall. The contraction suppresses the blood vessels surrounding the uterus, thereby deciding the blood and oxygen supply to the uterus. So it can be concluded that the physical exercise in the form of abdominal exercises stretching can decrease dysmenorrhea because it can relax the blood vessels ( Syatria, 2006 in Nurjanah, 2014).

The gate control theory state that exercise can inhibit or regulate the impulse of defense mechanisms along with the central nervous system. This theory suggests that pain impulses are delivered when a defense gate is opened and impulses are inhibited when a defense gate is closed. A balance of activity from sensory neurons and the descensus control fibers of the brain governing the defense process. The neurons of the delta $\mathrm{A}$ and $\mathrm{C}$ release the substance $\mathrm{P}$ to transmit pain impulses through $\mathrm{A}$ defense mechanism. In addition, there is A neuron beta A that is thicker and faster in releasing the inhibitory neurotransmitter. When the dominant stimulus comes from beta A-fibers, it closes the defense mechanism, the message will stimulate the mechanoreceptor or substance that can inhibit pain stimulation. However, when the dominant stimulation is from A and C delta fibers, it will open the defense and the client can pre-charge the pain sensation. Even if impulses are delivered to the brain, there is a higher cortex center in the brain that modifies pain. The descendent nerve groove releases endogenous opiates, such as endorphins and dinofin a natural pain killer that originates in the body by inhibiting the release of Substance P (Potter \& Perry, 2010).

The physical exercise proved to increase B-endorphin levels of four up to five times in the blood. So that more and more physical exercise will be the higher level B-endorphin. When a person performs a physical exercise, then B-endorphins will come out and are captured by receptors within the hypothalamus and limbic system that serve to regulate emotions. Increased B-endorphin levels proved to be closely related to pain decline, improved memory improvement of appetite and sexual ability (Harry, 2007).

\section{CONCLUSION}

The findings show that the average of the pain scale of dysmenorrhea in adolescent girls before abdominal stretching exercises is 6.16 (moderate pain) while after abdominal stretching exercises it is decreased into 3.27 (mild pain). There are the differences of pain scale before and after abdominal stretching exercises as it proves by pain scale which changes into 3.27. The pain scale reduced to 3.79. Bivariate statistical test obtained $p$-value $<0,001$. It proves that abdominal stretching exercises give great influences to reduce pain scale of dysmenorrhea in adolescent girls. 
Murtiningsih : The Effect of Abdominal Stretching Exercise on Dysmenorrhea in Adolescent Girls

Abdominal stretching exercises are recommended as an influential intervention in the nursing care of dysmenorrhea, especially for adolescent girls. This exercises can be a new routine activity for adolescent girls since it is very beneficial for them. Furthermore, it can be easier and can be conducted independently.

The further research can investigate more about the benefits of abdominal stretching exercises employing the different method and involving controlling group for the samples due to comparing the samples treated by abdominal stretching exercises and another group with another intervention such as aerobic exercises, yoga or pilates. Other research that can be recommended, for example, conducting research dealing with the effects of dysmenorrhea to the quality of life of adolescent girls.

\section{Acknowledgment}

Some funding for this research was supported by the Stikes Jenderal Achmad Yani Cimahi Jawa Barat Indonesia.

\section{REFERENCES}

Anderson, B. (2010). Stretching In The Office. Jakarta: PT Serambi Ilmu Semesta.

Bustan, M Najib et al. (2018). Abdominal Stretching Exercise in Decreasing Pain of Dysmenorrhea Among Nursing Students. IOP Conf. Series: Journal of Physics: Conf. Series 1028 (2018) 012103 DOI: 10.1088/1742-6596/1028/1/012103

Daley A. (2009). The Role of Exercise in The Treatment of Menstrual Disorder: The Evidence. Br J Gen Prac 59: 241-242

Danuatmaja. (2008). Persalinan Normal Tanpa Rasa Sakit. Jakarta: Puspawarna.

Dauglas W.Laube et al, (2010). Obstetrics and Gynecology. $6^{\text {th }}$ ed. Philadephia: Wolter Kluwer, Lippincott Williams \& Wilkins.

Harry. (2007). Mekanisme Endorphin dalam Tubuh. Diambil kembali dari http://www.klikharry.files.wordpress.com.

Hidayah, N. (2015). Pengaruh Latihan abdominal Stretching Exercise Terhadap Penurunan Dismenore pada Siswi Remaja di Madrasah Aliyah Hasyam Asy'ari Bangsari.

Gabeyehu, MB et al. (2017). Prevalence, Impact, and Management Practice of Dysmenorrhea among University of Gondar Students, Northwestern Ethiopia: A Cross-Sectional Study. Gondar Ethiopia: Creative Commons Attribution License.

Ningsih, R. (2011). Efektivitas Paket Pereda Nyeri Pada Remaja Dengan Dismenore. Jurnal Keperawatan Indonesia.

Nurjanah, A. A. (2014). Pengaruh Senam Aerobik Low Impact Terhadap Penurunan Dismenore Primer Pada Mahasiswi Diploma III Fisioterapi Universitas Muhammadiyah Surakarta . 
Murtiningsih : The Effect of Abdominal Stretching Exercise on Dysmenorrhea in Adolescent Girls

Pasero \& Chris, (2011). Pain Assessment and Pharmacologic Management. St. Louis, Missouri: Mosby Elsevier.

Potter, P. A., \& Perry, A. G. (2010). Fundamental Keperawatan Buku 1 Edisi 7. Jakarta : Salemba Medika .

Proverawati, A., \& Misaroh, S. (2009). Menarche Menstruasi Pertama Penuh Makna. Yogyakarta: Nuha Medika.

Rosemary. (2007). Promosi Kesehatan dan Ilmu Perilaku. Jakarta: RIneka Cipta.

S Saleh H, E Mowafy H, Hamied AA and El. (2016). Stretching or Core Strengthening Exercises for Managing Primary Dysmenorrhea. J Women Health Care; 5. Epub ahead of print February 9 DOI: $10.4172 / 2167-0420-1000295$.

Salbiah. (2012). Penurunan Tingkat Nyeri Saat Menstruasi Melalui Latihan Abdominal Stretching. Jurnal Ilmu Keperawatan.

Sultan C, Gaspari L, Paris F. (2012). Adolescent Dysmenorrhea. Endocr Dev 22: 171-80.

Thermacare. (2010). Abdominal Stretching Exercise for Menstrual Pain. Therma Kinetics.

Yanti. (2012). Gambaran Usia dengan Kejadian DIsmenore . 